\title{
A DEVELOPING MODEL OF RELATIONSHIP AMONG SERVICE QUALITY, CONSUMER SATISFACTION, LOYALTY AND WORD OF MOUTH IN ISLAMIC BANKING
}

\author{
Suryani \& Hendryadi $^{1}$
}

\begin{abstract}
A Developing Model of Relationship Among Service Quality, Consumer Satisfaction, Loyalty, and Word of Mouth in Islamic Banking. This research aims to develop a measurement tool of service quality in Islamic banking sector, and examine its relationship among satisfaction, word of mouth (WOM), and consumer loyalty. A convenience sampling of 235 respondents collected from seven locations in the Lhokseumawe, Aceh. Partial least square -structural equation modeling-(PLS-SEM) was used to test the research hypotheses. The results revealed that the quality of service has four dimensions, they are: service portfolio and assurance/SPA, tangibles/TAN, reliability of communication/COM, and Islamic values/IVA. The PLS-SEM results suggest that SPA and COM are dominant factors affecting satisfaction, and satisfaction were significantly related to WOM and loyalty. Loyalty also positively and significantly related to WOM.
\end{abstract}

Keywords: Service Quality, Islamic Banking, WOM, Loyalty, Customer Satisfaction.

Abstrak. Pengembangan Model Hubungan Antara Kualitas Layanan, Kepuasan Konsumen, Loyalitas, dan Kekuatan Komunikasi di Perbankan Syariab. Penelitian ini bertujuan untuk mengembangkan alat ukur kualitas layanan di sektor perbankan Syariah,dan menguji hubungannya dengan kepuasan, word of mouth (WOM), dan loyalitas nasabah. Sampel diambil dari 7 (tujuh) titik lokasi di Kota Lhokseumawe Aceh dengan total sampel 235 responden. Pemodelan persamaan struktural menggunakan SEM-PLS. Hasil analisis faktor menunjukkan bahwa kualitas pelayanan memiliki empat dimensi yaitu "portofolio layanan dan jaminan", "fisik", "keandalan komunikasi" dan "nilai Islami". Melalui analisis SEM-PLS dibuktikan bahwa portofolio layanan dan jaminan, dan faktor keandalan komunikasi adalah faktor utama yang mempengaruhi kepuasan nasabah, selain itu, dibuktikan bahwa kepuasan nasabah memiliki hubungan signifikan dengan WOM dan loyalitas, dan WOM juga terbukti berhubungan dengan loyalitas nasabah.

Kata Kunci : Kualitas Pelayanan, Bank Syariah, WOM, Loyalitas, Kepuasan Nasabah.

First draft: September, 18th 2014, Revision: November, 28th 2014, Accepted: December, $18^{\text {th }}$

${ }^{1}$ STAIN Malikussaleh Lhokseumawe, Jl. Medan-B.Aceh Km. 275 No. 1 Buket Rata, Alue Awe Kota Lhokseumawe

Faculty of Economic Attahiriyah Islamic University. Jl. Kampung Melayu III No. 15 Bukit

Duri Tebet Jakarta Selatan, DKI Jakarta

Email : suryapijar@yahoo.com, Hendry.basrah@gmail.com 


\section{Introduction}

Islamic bank is a bank that operates not on interest (riba), but using the principle of profit sharing (Mudharabah), safekeeping (Wadiah), a joint venture (Musyarakah), and leasing (Ijarah). Islamic bank also based on Islamic law (Sharia) that follows the Islamic rules and practices that stated in Holy Quran, Mohammad (PBUH) and majoring opinions among sharia scholars. Islamic Bank is a bank conducting business or operation based on Islamic principles and does not depend on the interest in providing financing and other services in transaction activity (Mohammed, 2005).

As a company involved in the field of service industries, quality of service in the Islamic banking sector has become a major concern in an effort to maintain competitiveness and long-term performance of the company. Superior service quality will increase customer satisfaction, loyalties and also will reduce the level of complaints and customer retention. Thus, companies that want to gain a competitive advantage should use technology to gather information about the demands of the market in an effort to improve service quality.

The implications of the intense competition between Islamic banks with conventional banks are increasing customers' standard banking services, so the approach of using religious sentiment is no longer effective in attracting consumers in the Islamic banking sector. Research conducted by Dusuki and Abdullah (2007) in Malaysia revealed that the selection of Islamic banks are dominated by a combination of reputation and quality of service and finance offered by banks. Other factors are also considered important that a good social responsibility comfort and price of the product. Further studies by Al-Tamimi et al., (2009) also found that the most important factors as determinants of bank selection, first, bank products, than service quality and religious factors. The results of different studies reported by Sayani and Miniaoui (2013) concluded that the determinants of bank selection are the preference religions as the most important consideration in choosing between Islamic and conventional banks.

Great attention to the quality of service the banking sector has made this topic develops and produces various models of measurement of service quality in the banking sector. However, there are considerable disagreement and debate about how to measure the quality of service. Generally, recent research using SERVQUAL as a tool to measure the quality of service throughout the marketing sector and this model has gained widespread evidence, but it is not possible for any other service sector, especially the banking sector (Abdullah et al., 2011). From 2000 to 2006, a total of 14 conceptual models of service quality reported that applied in the banking sector (both conventional and Islamic) (Sangeetha \& Mahalingam, 2011). 
Because there are many differences in the concept of service to the Islamic Bank then its prove, the concept is still being developed so as not yet found a definite reference in cross-cultural research. In addition, in developing the model in the measurement of service quality Islamic Bank, this research also tries to develop a research model to include satisfaction, word of mouth (WOM) and customer loyalty. Furthermore, this research is intended to enrich and provide knowledge in the context of Islamic Banking service quality and provides a conceptual framework for Islamic service quality that is still limited.

\section{Literature Review}

Business banking services primarily to give special attention to the trust, so the issue of service quality becomes a crucial factor in the success of the business. Service quality is a form of consumer ratings of the perceived service with the level of service expected. The implications of the quality of service according to Ladhari (2009), include increased customer satisfaction, improved customer retention, positive word of mouth, reducing staff turnover, reduced operating costs, enlarged market share, increase profitability, and improve financial performance.

Service quality is the result of the evaluation process, where consumers compare expectations with perceptions of service received (Grönroos, 1984). Another definition proposed by Parasuraman et al., (1988) which states that the service quality as a general assessment or attitudes related to service excellence, while satisfaction associated with a specific transaction. Service quality is generally seen as the result of a whole system of services received by consumers, and the principle that the quality of services focused on addressing the needs and desires of customers, as well as their determination to provide services in accordance with customer expectations. Service quality is the expected level of excellence and control of the level of excellence to meet customer expectations (Tjiptono and Chandra, 2004). Based on these definitions can be concluded that the service quality is the hallmark, the characteristics or properties of a product or service that can meet the expectations of consumers who provide a level of excellence in a specific service.

During its development, the service quality in the banking sector has been measured by various approaches, first, the model SERVQUAL of Parasuraman et al., (1988) proposed five dimensions of perceived service quality construction: first, tangibles or physical evidence, namely the ability of a company to show existence to external parties; Second, reliability is the company's ability to deliver as promised services accurately and reliably; Third, responsiveness is a willingness to help and provide fast and accurate service to customers with clear information; Fourth, guarantees and certainty is knowledge, courtesy, and the ability of the company's 
employees in growing confidence of the customers to the company; and Fifth, empathy is providing genuine concern and a private individual or given to customers by striving to understand the desires.

Most of the empirical studies on the quality of banking services are to measure the quality of service to replicate or adapt the model SERVQUAL. Firdaus Abdullah (2011) developed a factorial analysis showed that the quality of service has three dimensions, namely "systematization of service delivery", "reliable communication" and "responsiveness", and then some regression analysis showed that the "systematization" is the dimension of service quality the most important in the banking sector which is then referred to as the BSQ Index (Bank Service Quality). Other sizes referred to as the Bank Service Quality (BSQ) developed by Bahia and Nantel (2000) which measures the quality of the bank's services include aspects of effectiveness and assurance; access; price; tangibles; service portfolio, and reliability that also successfully validated by Glaveli et al., (2006) through his research in five countries.

Compared to conventional bank, service quality measurement in the Islamic banking sector is still relatively limited. Several studies have attempted to develop a service quality scale Islamic Bank as Gayatri and Chew (2013) identified: Islamic values in general, halal/haram, attention to the activities of the Islamic religions, honesty, humility, and humanity and trust. While Manshor Taapet Amat al., (2011) using the four dimensions of service quality, namely tangibility, reliability, competence, and comfort in Islamic and conventional banking sector in Malaysia. Jabnoun and Khalifa (2005) developed a measure of quality of service to the conventional banks and Islamic banks and they identified four dimensions that include personal skills, reliability, value and image of the bank. However, only the dimension values and personal skills that significant in determining the quality of service in Islamic banks. Research by Misbach et al., (2013) conducted in Indonesia adapted the measurement model of Abdullahet al., (2011) designed a new measurement instruments in the banking sector and identifies three dimensions that include system services, responsiveness and reliability. Thus, Qureshiet al., (2014) in Pakistan used the measurement model by adapting the SERVQUAL, which includes reliability, responsiveness, assurance, empathy, and physical aspects. Models of service quality measurement can be seen in Table 1 .

Table 1. Model of Service Quality Measurement In Islamic Bank

\begin{tabular}{llll}
\hline Writer / Year & State & & Model Of Measurement / Indicator \\
\hline Jabnoun dan & Uni & Emirat & Personal skills, reliability, value and \\
Khalifa (2005) & Arab & & image of bank
\end{tabular}




\begin{tabular}{|c|c|c|}
\hline $\begin{array}{l}\text { Ahmad et al., } \\
(2010)\end{array}$ & Pakistan & SERVQUAL \\
\hline $\begin{array}{l}\text { Ladhari et al., } \\
\text { (2011) }\end{array}$ & $\begin{array}{l}\text { Kanada dan } \\
\text { Tunisia }\end{array}$ & SERVQUAL \\
\hline $\begin{array}{l}\text { Amat Taap et al., } \\
(2011)\end{array}$ & Malaysia & $\begin{array}{l}\text { Honesty, humility, humanity and } \\
\text { trust }\end{array}$ \\
\hline $\begin{array}{l}\text { Gayatri dan Chew } \\
\text { (2013) }\end{array}$ & Indonesia & $\begin{array}{l}\text { Islamic values in general, halal } / \\
\text { haram, attention to the activities of } \\
\text { Islamic religion, honesty, humility, } \\
\text { humanity and trust }\end{array}$ \\
\hline $\begin{array}{l}\text { Misbach et al., } \\
(2013)\end{array}$ & Indonesia & $\begin{array}{l}\text { System service, responsiveness and } \\
\text { reliability }\end{array}$ \\
\hline $\begin{array}{l}\text { Amirzadeh dan } \\
\text { Shoorvarzy (2013) }\end{array}$ & Iran & SERVQUAL \\
\hline $\begin{array}{l}\text { Qureshi et al., } \\
\text { (2014) }\end{array}$ & Pakistan & SERVQUAL \\
\hline
\end{tabular}

Consumer behaviors such as loyalty, repeat purchases, the level of complaints, word of mouth, brand image, customer value, and various other aspects. The relationship between service quality and consumer satisfaction in the banking context has been studied. One study tried to develop a model of the relationship between service quality, customer satisfaction, and profitability of banks in Taiwan. By using the models SERVPERF successfully proved that service quality has a positive relationship with customer satisfaction and profitability of banks (Lee and Hwan, 2005).

Research in Malaysia proves that the five key dimensions of competence, communication, conflict management, trust, and relationship quality-discrimination between customers associated with consumer satisfaction (Nelson and Chan, 2005). Another study in India found that customer expectations and perceptions of service quality dimensions of tangibility, competence and empathy have an impact on consumer satisfaction (Khurana, 2014). Newer research reveals similar findings as Esmailpour et al., (2012) and Mosahab et al., (2010) in Iran; and Al-Hawari (2008) in Australia. Based on the above, it can be said that the better the quality of services provided the higher the level of satisfaction.

The hypothesis is: "H1: Service quality is positively related to customer satisfaction".

A satisfied customer will provide recommendations on experience to others are a basic concept of communication by word of mouth. Word of mouth can be expressed as interpersonal communication between two individuals even more like 
a consumer's group members or others. Due to the nature of the recommendations of the individual, the communication of mouth is one of the important factors that influence a person's decision to buy. WOM concept definition itself is constructed differently, such as the informal transfer of positive or negative purchases and behaviors associated with consumption among consumers (Teo and Soutar, 2012). In the education sector, it was found that the functional quality of service, rather than the quality of technical services, have an impact on the formation of WOM, with student satisfaction plays an important mediating role (Teo and Soutar, 2012); satisfaction associated with loyalty and WOM (Shao-Chang Li, 2013); and the high satisfaction of a larger cause WOM activity (Lang, 2011). Thus, it is reasonable to think that in a banking context, the fulfillment of the expectations that have implications for consumer satisfaction will lead to an increase in intention to recommend to others about their experiences with others in the form of positive WOM. Thus, the second hypothesis proposed is:

$\mathrm{H} 2$ : "Consumer satisfaction is positively associated with WOM"

Consumer loyalty is a form of behavior. Loyal customers will demonstrate the purchase of non-random behavior, repeated violations of the goods / services of a company. The word "non-random" on buying behavior indicates that loyal customers make purchases planned and not based on random events (Griffin, 2009). While the characteristics of loyal customers according to Kotler and Keller (2009) can be seen from the three indicators includes repeat purchases; resistance from other influences and referrals or refer in total company's existence.

In various literatures, customer satisfaction is an important indicator of customer loyalty and a number of studies have identified the benefits of customer loyalty for the company in the future. The benefits of customer loyalty can lead to low service cost because the cost to be incurred by the company for loyal customers is cheaper than new customers. In addition, they will pay a higher fee for a set of products; and loyal consumers will act as an agent of word-of-mouth marketing. (Gee et al., 2008).

Research conducted by Pont and McQuilken (2005) on the relationship between customer satisfaction and loyalty in the Australian banking industry to the conclusion that satisfaction has a significant impact on three of the five dimensions: loyalty, pay more and external responses, Whereas the other two dimensions, namely the tendency to switching and internal response is not significant. In the context of e-banking services, satisfaction has a significant effect on loyalty to the bank and a willingness to continue the relationship with the e-banking services (Momeni et al., 2013). Other studies such as that carried out by Kazemi et al., (2013) give the conclusion of the relationship between brand identity, customer 
loyalty and WOM by considering the mediating role of customer satisfaction and brand commitment.

Other empirical evidence also found that all the attributes of service quality are positively related to customer satisfaction is positively related to customer loyalty in retail banking arrangements in Bangladesh. Empathy showed the highest positive correlation with customer satisfaction and physical aspects showed a positive correlation with customer satisfaction at least (Siddiqi, 2011). Based on these explanations, the proposed hypothesis is:

H3: "Loyalty is positively associated with WOM" and H4: "customer satisfaction is positively related to loyalty"

\section{Methods}

Service quality in this study adapted various service quality measurement model of Bank. Through a preliminary study identified 26 items relevant statements by adapting measurement model of Bank Service Quality (BSQ) from Bahia and Nantel (2000); Service quality measurement model Islamic Bank of Gayatri and Chew (2013); and SERVQUAL of Parasuraman et al., (1988). Customer satisfaction is measured by three items include overall satisfaction, the level of complaints, compliance with the expected services, and the lack of service (Hennig, 2004). Loyalty is measured by two items covering the intention to continue to be a customer and intention to move (Dimitriades, 2006). WOM is measured by three items include the intention to tell others, recommend behavior, and behavior to invite others to use the services of Islamic Banks (Shao-Chang Li, 2013). All statements are measured using a scale of 7 point Likert-type items, namely 1 (strongly disagree) to 7 (strongly agree).

The first stage of analysis using exploratory factor analysis (EFA) by the method of principal component analysis and varimax rotation was used as a test tool to test the factor structure of the data. The factor analysis would classify data based on the inter-correlations between items. The reliability of a measurement indicates the extent to which these measurements without free from errors and ensure consistent measurement across time and across a variety of items in the instrument. The approach used to estimate the reliability of the instrument is using the Cronbach alpha coefficient. Reliability test was using internal consistency approach. Cronbach alpha value of 0.70 and above is considered the criteria to demonstrate the internal consistency of the scale developed.

The analysis technique used to test the model of the relationship among variables in this study is a structural equation model - partial least square (PLS-SEM). 
This technique is an alternative method used to model that has great complexity, an indicator that is reflexive and formative mix and has a purpose for prediction (Ghozali, 2008).

\section{Discussion}

Through a convenient technique (simple sample) then obtained 235 respondents obtained from six Islamic Banks in Lhokseumawe and the location was taken in one of the Islamic Universities. The sample consisted of $47.7 \%$ male and $52.3 \%$ female. Age of respondents consisted of less than 25 years $(39.6 \%)$, then the age of $26-35$ years (34\%), over 35 years $(24.3 \%)$ and $2.1 \%$ are refused to filled. Majority, the education respondent is bachelor (37.4\%) and high school (36.6\%), while based on the length of a customer, the customer as much as $52.8 \%$ less than 3 years, and $26.4 \%$ between $4-8$ years, and $12.3 \%$ are already a customer of more than 9 years, and $8.5 \%$ of respondents are refused to answer.

Through factor analysis values obtained Kaiser-Meyer-Olkin MSA (KMOMSA) of 0.933 shows that the data have been qualified analysis of the first factor. Second, the value of Bartlett's Test of Sphericity of 4309.445 at 0.000 significance. This value indicates that the variable-forming factor is good enough so that the analysis can proceed. The next step is to assess the communality of each variable to determine which items are examined as a value factor. The results showed that the two variables are communalities below 0.50 so that it is removed from the measurement model. Furthermore, based on the total variance explained earlier revealed 24 items forming four factors with eigenvalue over one. Four of these factors explain about 64,496 percent of the variance. After two items are eliminated, then the ability of four factors explains construction is of $67,843 \%$. Thus, the final scale is used, leaving 24 item questionnaires of 26 questions planned. Table 1 shows the results of factor analysis in terms of the name of factors. Variables loading on each factor, and the variance explained by each factor. Alpha coefficient values for all factors of service quality are shown that all factors that meet the prerequisites of reliability Cronbach alpha $>0.70$. It can be concluded that the four constructs have a satisfactory level of reliability.

The results of testing the validity of the structure on customer satisfaction generate value Kaiser-Meyer-Olkin (KMO) measure of sampling adequacy for $0,747$ (chi-square $=398,519, \mathrm{df}=3, \mathrm{sig}=0.000)$. The total variance explained demonstrates the ability to explain construct three items of 81,890 customer satisfactions. Furthermore, the conclusion that the entire item is valid with regard weighting coefficient factor> 0:50. Internal consistency with Cronbach alpha tests to qualify the reliability that is equal to 0,887 . for WOM construct, the value of 
Kaiser-Meyer-Olkin (KMO) measure of sampling adequacy for 0,742 (chi-square $=449007, \mathrm{df}=3, \mathrm{sig}=0.000)$. All the items proved to be valid by the ability to explain the construct of 83,651. Internal consistency Cronbach's alpha tested by a qualified reliability that is equal to 0,902 . And test results on the loyalty construct showed the value of the Kaiser-Meyer-Olkin (KMO) measure of sampling adequacy of 0.500 (chi-square $=102245, \mathrm{df}=1$, sig $=0.000$ ), with a totals of $80,282 \%$ constructs the ability to explain. Internal consistency (alpha cronbach) 0,887 for customer satisfaction, 0,902 (WOM), and 0,754 (loyalty) and has fulfilled a good reliability (Cronbach alpha> 0.70 ).

Measurement model with reflexive indicator based composite reliability or internal consistency should be higher than 0.70 (in exploratory research, 0.60 to 0.70 are considered acceptable); second, reliability indicators: loading factor on the indicator must be higher than 0.70 . Third, convergent validity seen from the average variance extracted (AVE) should be higher than 0.50. Fourth, discriminant validity: the square root of AVE any latent constructs should be higher correlation latent variables; and loading factor indicators should be higher than the other constructs (Hair et al., 2011). Further, reliability test shows that all variables have a value of composite reliability and Cronbach alpha above 0.70 . So it can be stated that all latent variables have a good level of reliability.

Convergent validity is met if the scores obtained by two different instruments that measure the same concept shows a high correlation. Indicators which have convergent validity is having outer loading factor above 0.70 . The next test results shown that all the indicators already have a loading factor $>0.70$ so that it can be declared to have proved it has a convergent validity.

Discriminant validity was intended to test that a properly construct only measure the construct to be measured, not the other construct. Discriminant validity testing methods can use cross-loading between indicators and used the roots of the average variance extracted (AVE). Through the results of the analysis shows that the correlation for each indicator in latent variables is greater than other latent construct. In addition, test results showed that the root of AVE entire square root of the construct has a greater value than the correlation between the latent variables. From this test it can be concluded that the model has met the discriminant validity.

The Goodness of Fit model is measured using R2 dependent latent variable with the same interpretation of the regression. $R^{2}$ value of $0.75,0: 50$ or $0: 25$ for endogenous latent variables in the structural model can be described as substantial, moderate and weak. Q2 predictive relevance for the structural model to measure how well the observed values generated by the model and parameter estimation. $\mathrm{Q}^{2}$ value greater than zero indicate that the construction of exogenous have predictive 
relevance in explaining endogenous. (Hair et al., 2011).

Based on the analysis of SEM-PLS obtained $\mathrm{R}^{2}$ structural model in model 1 (satisfaction) is equal to 0732 , model 2 (WOM) is equal to 0505 and model 3 (Loyalty) is equal to 0492 . Thus the formulas and calculations to test predictive relevance $\mathrm{Q}^{2}$ following:

$$
\begin{aligned}
& \mathrm{Q}^{2}=1-\left(1-\mathrm{R}_{1}^{2}\right)\left(1-\mathrm{R}_{2}^{2}\right)\left(1-\mathrm{R}_{3}^{2}\right) \\
& \mathrm{Q}^{2}=1-(1-0.732)(1-0.505)(1-0.492) \\
& \mathrm{Q}^{2}=1-(0.268)(0.495)(0.508) \\
& \mathrm{Q}^{2}=0.933
\end{aligned}
$$

Summary of Hypothesis tests show of five of seven proposed hypothesis supported. Two non-significant path coefficient are the relationship between the physical aspect (TAN) with satisfaction (SAT) and the relationship of Islamic values (IVA) with satisfaction (SAT).

This study consists of two main objectives: first to develop an instrument to measure the quality of Islamic banking services, and the second is a test model the relationship between service quality, satisfaction, and loyalty WOM. The results of the analysis successfully validated 24-item scale measuring service quality Islamic Banks (Islamic Bank service quality scale / iBSQ). As a newly developed scale, these findings provide initial information to be replicated in future studies. This study complements the findings of Gayatri and Chew (2013) which identifies the Islamic Bank of service quality measures include: Islamic values in general, halal/haram, attention to the activities of the Islamic religion, honesty, humility, and humanity and trust, and Bank Service Quality (BSQ) developed by Bahia and Nantel (2000) which measures the quality of the bank's services include aspects of effectiveness and assurance; access; price; tangibles; service portfolio; and reliability which also successfully validated by Glaveli et al., (2006). In summary, this study enriches and increases their knowledge in the context of quality Islamic banking services and provides a conceptual framework for service quality which is still relatively limited explored.

Compared with previous studies, such as Gayatri and Chew (2013) which identifies six factors of service quality Islamic Bank, this study identified only four the quality factor of Islamic banking services by using the more general aspects that are expected to be able to describe the professional quality of the Islamic banking services. Interesting findings is the lowest average score of 4 dimensions are used for 6 (six) that is observed Bank of the Islamic values. This situation clearly needs to get attention from the Islamic Bank in its efforts to reinforce the distinction of Islamic banks with conventional banks. 


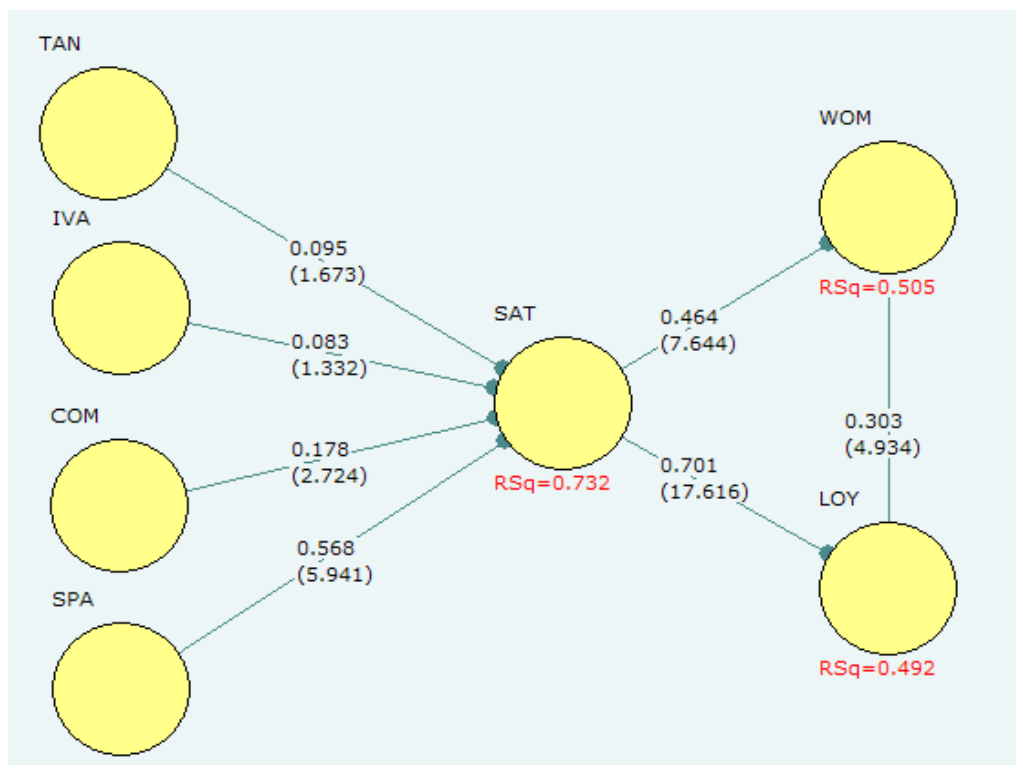

Figure 1. Structural Model PLS-SEM

Through the analysis of SEM-PLS obtained results indicate that physical factors (TAN) and Islamic values (IVA) has not significantly related to satisfaction, with $t$ value for each coefficient of 1,673 and 1,332. Two other factors, namely the reliability of communications (COM) and the portfolio of services and guarantees (SPA) has a significant relationship (0178, $\mathrm{t}$ value 2,724 t) for COM and 0.568 ( $t$ value 5,941 $t$ ) for SPA. Thus it can be stated the relationship between service quality and customer satisfaction is only partially supported ( $\mathrm{H} 1 \mathrm{a}$ and $\mathrm{H} 1 \mathrm{~b}$ are not supported; H1c and H1d supported). In the second sub-structural WOM as an endogenous variable, obtained coefficient of determination of 0505 which demonstrate the ability of consumer satisfaction and loyalty explain WOM by $50.50 \%$. Coefficients between consumer satisfaction to WOM that are for 0.464 ( $t$ 7.644) and coefficient of loyalty to WOM that are for 0303 ( $t$ 4.934). The two coefficients significant at $5 \%$ level that can otherwise be otherwise be able to explain the variation of WOM, therefore hypotheses 2 and 3 supported. Sub-structural third placing loyalty as an endogenous obtained coefficient of determination of 0.492 which describes the ability of customer satisfaction in explaining loyalty amounted to $49.20 \%$. Coefficient path of satisfaction on loyalty is equal to 0.701 ( $\mathrm{t}$ value 17 . $616 \mathrm{t}$ ), so that the Hypothesis 4 is supported. 


\section{Conclusion}

Based on testing the validity and reliability that have been described, the four factors which successfully identified in this study: first, portfolio of services and warranty (service portfolio and assurance) service product portfolio refers to the diversity of services offered, the results and the fees charged to customers. Collateral refers to the accuracy of the services such as errors in service, gives a detailed explanation on the services offered, the service compared with conventional banks, the suitability of hope, and the suitability of the promise. Second, physical factors (tangibles). This factor relates to buildings, neatness and design rooms, location, service staff clothing. Third, communication reliability factor (reliable communication). The reliability of communication refers to communication effectiveness in providing services (especially the friendliness and courtesy of employees) and the willingness of staff to provide an explanation to the customers. These factors emphasize the need for staff in providing services which promote good attitudes and behavior by promoting hospitality (empathy) and courtesy (modesty) in the face of the customer, including in the case of listening to the complaints submitted. Fourth is the factor of Islamic values and attention to Islamic activities. This factor explains conformity with Islamic values such as conformity with the rules of Islam, Muslim accommodate customer needs, prioritizing system halal/ haram, and provide tools for the activity of Islamic prayer.

This research is targeted also to explain the relationship between service quality and customer satisfaction, and the relationship between customer satisfaction, loyalty, and WOM. Statistical analysis showed that only two lanes direct effect of service quality on customer satisfaction, namely the reliability of communications $(\mathrm{COM})$, portfolio and collateral (SPA). Two factors of service quality that physical factors (TAN) and Islamic values (IVA) is not proved significantly related to customer satisfaction. Although the structure of these two factors proved to have construct validity, but each one is weak in terms of validity based criteria (criterionrelated validity) that validity is determined by comparing the test scores with certain performance on an external measure. Beyond this size should have a theoretical relationship with the variables measured by tests that, in this context that are the quality of service should correlate with customer satisfaction. A larger sample size is recommended for further testing, as recommended by Hair et al., (2006) that 14 to 1 or $14 \times 32$ variables / items $=448$.

Another finding that successfully authenticated that is positively WOM can be explained by the satisfaction and loyalty, and the latter proved satisfaction is positively related to loyalty. Customers which satisfied with the quality of service will create loyalty to generate WOM behavior. 


\section{References}

Abdullah, F. et.al. 2011. Bank Service Quality (BSQ) Index: An Indicator of Service Performance. International Journal of Quality \& Reliability Management. Vol. 28 Iss: 5.

Al-hawari, M. 2008. The Influence of Traditional Service Quality Factors on Customer Satisfaction: A Practical Study within the Context of Australian Banking. The Business Review. Cambridge. Dec Vol. 11, No. 2.

Asyraf, W.D. \& N.I. Abdullah. 2007. Why do Malaysian Customers Patronise Islamic Banks?. International Journal of Bank Marketing. Vol. 25 Iss: 3.

Bahia, K. \& J. Nantel. 2000. A reliable and Valid Measurement Scale for Perceived Service Quality of Bank. International Journal of Bank Marketing. Vol. 18 No. 2.

Dimitriades, Z.S. 2006. Customer Satisfaction, Loyalty and Commitment in Service Organizations: Some Evidence from Greece. Management Research News. Vol. 29, No. 12.

Esmailpour, M. et.al. 2012. The Influence of Service Quality on Customer Satisfaction: Customers of Boushehr Bank Sepah as a Case Study. Interdisciplinary Journal of Contemporary Research In Business, Jan Vol. 3, No. 9.

Gayatri, G \& J. Chew. 2013. How do Muslim Consumers Perceive Service Quality. Asia Pacific Journal of Marketing and Logistics. Vol. 25 Iss: 3.

Ghozali, I. 2008. Structural Equation Modeling Metode Alternatif dengan Partial Least Square. Semarang: Badan Penerbit UNDIP.

Glaveli, N., Petridou, E., Liassides, C, \& Spathis, C. 2006. Bank Service Quality: Evidence from Five Balkan Countries. Managing Service Quality. Vol. 16 Iss: 4.

Griffin, Jill. 2009. Customer Loyalty: How to Learn It, How to Keep It. Jakarta: Erlangga.

Hameedah, S. \& H. Miniaoui. 2013. Determinants of Bank Selection in the United Arab Emirates. International Journal of Bank Marketing, Vol. 31 Iss: 3.

Jaya, S. \& S. Mahalingam. 2011. Service Quality Models in Banking: a Review. International Journal of Islamic and Middle Eastern Finance and Management, Vol. 4 Iss: 1.

Kazemi, A. et.al. 2013. Impact of Brand Identity on Customer Loyalty and Word of Mouth Communications, Considering Mediating Role of Customer Satisfaction and Brand Commitment. (Case Study: Customers of Mellat Bank in Kermanshah). International Journal of Academic Research in Economics and Management Sciences. Vol. 2. No.4.

Khurana, S. 2014. The Relationship Between Service Quality and Customer Satisfaction: 
An Empirical Study of the Indian Banking Industry. IUP Journal of Bank Management. Nov. Vol. 13. No. 4.

Kotler, P. \& Keller, K.L. 2009. Marketing Management (Indonesian version). Jakarta: Indeks.

Lang, B. 2011. How Word of Mouth Communication Varies Across Service Encounters. Managing Service Quality. Vol. 21. No.6.

Manshor, A.T. et.al. 2011. Measuring Service Quality of Conventional and Islamic Banks: a Comparative Analysis. International Journal of Quality \& Reliability Management. Vol. 28 Iss: 8.

Misbach, I. et.al. 2013. Islamic Bank Service Quality and Trust: Study on Islamic Bank in Makassar Indonesia. International Journal of Business and Management. Vol 8. No.5.

Mosahab, R. et.al. 2010. Service Quality, Customer Satisfaction and Loyalty: A Test of Mediation. International Business Research. Oct. Vol. 3. No. 4.

Nelson, N.O. \& K.W. Chan. 2005. Factorial and Discriminant Analysis of the Underpinnings of Relationship Marketing and Customer Satisfaction. International Journal of Bank Marketing. Vol. 23. No. 7.

Parasuraman, A. et.al. 1988. SERVQUAL: a Multiple Item Scale for Measuring Consumer Perception of Service Quality. Journal of Retailing. Vol. 64. No. 1.

Qureshi, M.I. et.al. 2014. Structural Investigation of Service Quality in Conventional and Islamic Banking in Pakistan. International Journal of Management and Innovation. Vol. 6. No. 1.

Siddiqi, K.O. 2011. Interrelations between Service Quality Attributes, Customer Satisfaction and Customer Loyalty in the Retail Banking Sector in Bangladesh. International Journal of Business and Management. Mar Vol. 6. No. 3.

Teo, R \& G. Soutar. 2012. Word of Mouth Antecedents in an Educational Context: a Singaporean Study. The International Journal of Educational Management. Vol. 26. No.7.

Tjiptono, F. \& G. Chandra. 2004. Service, Quality \& Satisfaction. Yogyakarta: ANDI. 